\title{
Case Report of Fibrous Dysplasia of Maxillary Region
}

\author{
Dr. Arth Shah ${ }^{1}$,Dr. M.F. Shaikh ${ }^{2}$,Dr. Hiren Rana ${ }^{3}$,Dr. Hardik Dodia ${ }^{4}$ \\ ( $3^{\text {rd }}$ Year Resident, Department Of Burns And Plastic Surgery, B. J. Medical College/ \\ Gujarat University, India) (Head Of The Department, Department Of Burns And \\ Plastic Surgery, \\ B. J. Medical College/ Gujarat University, India) \\ ( ${ }^{\text {rd }}$ Year Resident, Department Of Burns And Plastic Surgery, B. J. Medical College/ \\ Gujarat University, India) \\ ( $2^{\text {nd }}$ Year Resident, Department Of Burns And Plastic Surgery, B. J. Medical College/ \\ Gujarat University, India)
}

\begin{abstract}
:
Introduction: The Fibrous Dysplasia is a benign bone disease, of slow growth and unknown etiology. The involvement of the craniofacial skeleton is not uncommon and, generally, produces facial asymmetries.

Case Report: In this article we report the case of a patient with fibrous dysplasia occupying the entire left maxillary sinus with orbitary extension confirmed in the anatomopathological exam.

Final Comments: The surgical treatment remains as the main therapeutic approach and the postoperative follow-up is necessary due to this condition recurrent nature.
\end{abstract}

Keywords: Fibrous Dysplasia, Maxillary growth, Maxillary fibrous dysplasia, Facial swelling, Management of maxillary fibrous dysplasia

\section{Introduction}

The Fibrous Dysplasia is a fibro-osseous lesion characterized by the replacement of normal elements of the bone for a disorganized fibrous tissue. It represents $2 \%$ of the osseous tumors

1. The first author to describe the characteristic osseous lesion, today known as fibrous dysplasia, was Von Rechlinghausen in 1891, but it was Lichtenstein, in 1938 who introduced the term fibrous osseous dysplasia into the worldwide literature

2. There are two primary categories of the disease: monostotic fibrous dysplasia, that involves only one bone and represents $70 \%$ of the cases; and polyostotic fibrous dysplasia, that presents the involvement of several bones. It is generally developed at the end of the childhood with prevalence in the male sex $(2: 1)$ and has a major preference for the white race

3. The craniofacial skeleton is a frequent region of the disease, which may cause organic, aesthetic and psychological disorders.The diagnosis suspicion is made by clinical and radiological methods which need anatomopathological confirmation

4. The typical radiological exam shows a characteristic aspect of "opaque glass" involved by a dense cortical tissue

5. The definitive treatment is the lesion surgical excision. The clinical follow-up of the patient is essential for the early diagnosis of a recurrence. We describe one case of maxillary bone fibrous dysplasia that, in spite of its benign nature, caused facial deformity.

\section{Case Report}

The 26-year-oldmale, patient from Vadodara, was referred to the department of burns and plastic surgery with a clinical picture of a progressive increase in the left hemiface. He denied headache, deficit of visual accuracy, otalgia, nasal obstruction and toothache. He mentioned one case of sinusitis 1 year before. The clinical exam, good general state, the evaluation of the organic systems didn't reveal alterations. Absence of lymphonodomegalia and cutaneous stains. He presented with a painless tumoration in the left jaw and zygoma with normal subjacent oral skin and mucosa (Picture 1 and 2). 

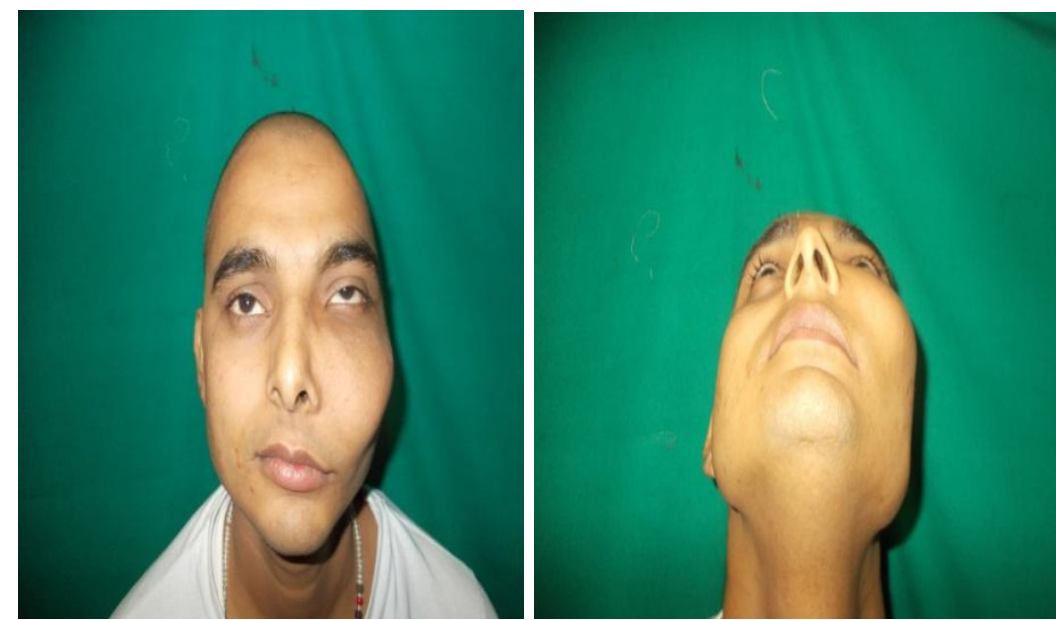

Picture 1 and 2. View of the patient in the frontal decubitus position with evidence of convexity in the left hemi face.

The Computed Tomography of the face sinuses showed a hyperdense, heterogeneous, expansive mass of uneven contour, with aspect of an "opaque glass" involving the maxilla, zygomatic bone and left maxillary sinus (Pictures 3 and 4)
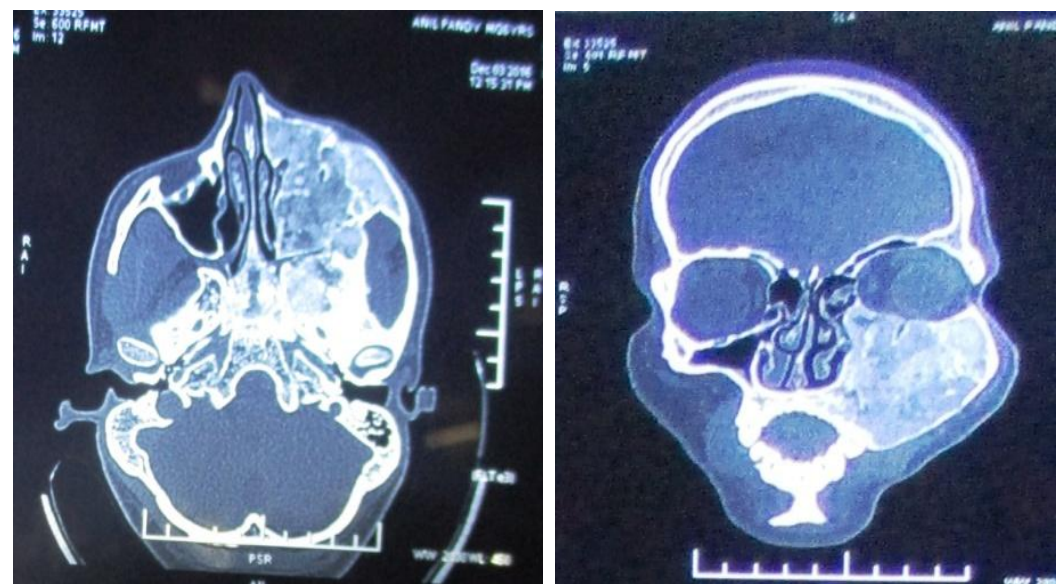

Picture 3 and 4. Showing Axial cut of $\mathrm{CT}$ of the face sinuses showing a tumor with heterogeneous density occupying the left maxillary sinus with aspect of opaque glass and Coronal cut of $\mathrm{CT}$ of face showing mass extension to the orbit floor respectively.

After adequate planning and consent, surgical excision of diseased maxilla was done. Maxillectomy was done using extraoral approach. 15 gram of diseased bone removed and sent for histopathology examination whose report came out to be fibrous dysplasia. Post operatively patient had good hospital course and was discharged on $10^{\text {th }}$ day. Suture removal done on $21^{\text {st }}$ day. Patient is satisfied with the result. On follow up visits no increase in bone at surgical site is seen till date. Postoperative follow up pictures ar pictures 5 and 6 as follows.
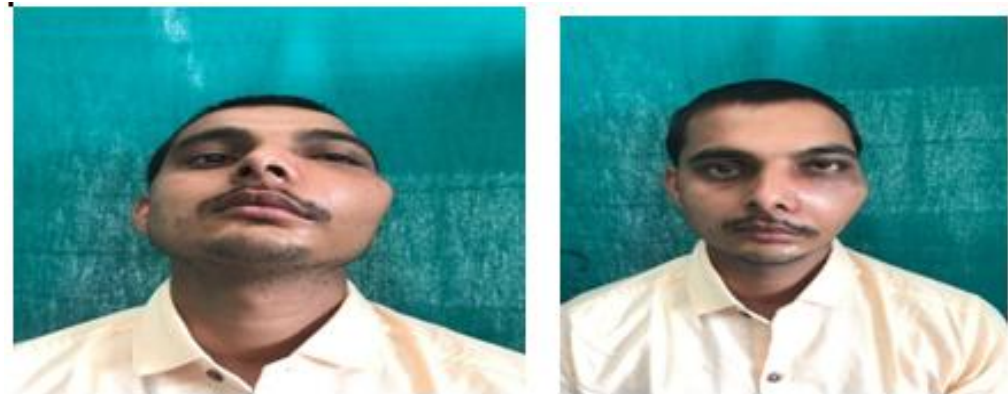

Picture 5 and 6 Showing postoperative picture on day 21 after suture removal. Scar is good and facial contour is improved. 


\section{Discussion}

The Fibrous Dysplasia (FD) is defined as a benign osseous disease characterized by a process of normal bone reabsorption, followed by an abnormal proliferation of a disorganized fibro-osseous tissue (1). It represents about $7 \%$ of all benign osseous tumors and may affect any bone of the skeleton (6).

It's classified as for the number of affected bones and the presence or not of extra-skeleton abnormalities. The monostotic form affects only one bone and corresponds to $70-80 \%$ of the FD cases. The polyostotic form, in which several bones are affected, may be divided into three subtypes: craniofacial, in which only the craniofacial complex are involved including the jaw and the maxilla; Lichtenstein-Jaffe, in which in addition to the several skeleton bones involvement there are coffee-with-milk pigmentations; Albright's Syndrome, characterized by the affection of several bones, coffee-with-milk pigmentations in the skin and endocrine affection with a remark for the early adolescence in girls. The polyostotic form corresponds to 20$30 \%$ of the cases (7). The craniofacial bones are more affected in the polyostotic form (50-100\%) than in the monostotic form $(20 \%)(4)$.The FD etiology is controversial. Lee e col. proposed that the abnormalities in the AMPc or kinase protein intracellular regulation etiologic factors are possible in the development of the FD. Other researchers have identified mutations in the GNAS gen, which result in the GTPase activity alterations, with a consequent increase of the AMPc intracellular concentrations (8).It manifests more frequently in the childhood and, however, is not exclusive of this age range $(4,9)$. It has an usually slow evolution, a tendency to stabilize after adolescence and a high recurrence rate $(2,9,10)$. Such characteristics have a strong implication in the therapeutic approach. As for the distribution of the disease by sex, there is no uniformity between the studies $(6,9,10)$.

The disease is initially asymptomatic. The FD signals and symptoms depend on the location of the lesion(s) and the compressive effect in the adjacent structure as the tumor progresses slowly: facial asymmetry and deformity; pathological fractures; obstruction of the paranasal sinuses which generate recurrence infections, cysts and mucoceles; anosmia; headache; loss of visual accuracy for compression of the optic nerve; alteration of the ocular movements; descent; exophthalmia, squint; conductive hearing loss $(4,9,11,12)$.The CT is the choice exam for the study of the lesion(s), analysis of their extension and surgical preparation $(6,11)$. Basically, three radiographic standards in the cranium fibrous dysplasia and facial bones are described: pategoid, that alternates the radiodense and radiotransparent areas; sclerotic, homogeneously dense; cystic standard, with spherical or ovoid radiolucid area surrounded by dense limits (12). In the case reported, the lesion tomographic images presented a hyperdense standard intermixed by imprecise limits hypodense areas, which resulted in the classical aspect of "opaque glass". The FD definitive diagnosis is made by the correlation of clinical, radiological and anatomopathological findings (13).

The FD macroscopic exam reveals an expansion of the osseous trabeculate into a thin cortical; as there is no definitive capsule, there occurs an abrupt transition into the healthy bone. The microscopic evaluation shows a collagen matrix stroma with fibroblasts in a entangled standard with osseous trabeculate similar to the "Chinese writing" (12).The FD differential diagnosis includes malignant (sarcoma, metastatic osteoblastic lesions) and benign lesions (ossifying fibroma, Paget's disease, aneurismatic osseous cyst, cystic Cristeller Syndrome, ameloblastoma, osteochondroma, hyperthyroidism etc.) $(1,6,8,10,12)$. The main factors that guide the FD approach are the presence and the intensity of the symptoms, the tumor location and the patient's age. The simple presence of the lesion does not justify surgical intervention. The main indications for surgical treatment of FD are the presence of significant clinical symptoms and the control of large aesthetic deformities $(2,9)$. Because of the lesion benign nature and its recurrence character $(10-20 \%)$, the surgery must be relatively conservative with the main objective of preserving the function (9). In this case, we chose an expectant procedure, not only for the absence of organic and functional alterations, in spite of the aesthetic involvement, but also because of the age of the patient. He keeps on quarterly service follow-up until his growth and adolescent development is complete.Radiotherapy is counter-indicated not only because the tumor is radioresistant but also because of the probable increase of the capacity for the dysplasia sarcomatous transformation, whose estimates range from less than $0.5 \%$ of its natural evolution to about $44 \%$ after radiotherapy $(2,9)$.

The isolated clinical treatment or associated to surgery has been reported in the literature and there are disagreements as for their benefits in FD. Lustig reports that, for inhibiting the osteoclasts, the biphosphonates are employed in the treatment of patients with osteodystrophies, but that their effects in DF have been limited (9). Moreno reports the following benefits in patients treated with biphosphonates: improvement of pain and inflammatory symptoms, stabilization and reduction of bone destruction, increase of the osseous density, recalcification of osteolytic lesion in $50 \%$ of the patients, improvement of the radiologic aspects and the osseous metabolism(6).Some authors defend the need for a clinical, endocrinologic study and cintilography with Tc 99 in the patients with diagnosis of Monostotic Fibrous Dysplasia in search of other lesions, other regions and extra-skeleton nvolvement $(6,11)$. The clinical and radiological follow-up by $\mathrm{CT}$ is essential in the patients with 
FD because of the moderate recurrence rate of the lesion(s) which may reach $37 \%$ according to some authors (9).

\section{Final Comments}

The Fibrous Dysplasia is significant for the otorhinolaryngology because it may affect facial and cranial bones and may cause deformities and dysfunctions. In spite of its benign nature, the signals and symptoms resulting from the compression of noble structures of the cranial base and orbit may generate diagnostic doubts as for the possibility of a malignant lesion. The surgical treatment must take into account the disease's harmful and recurrent potential, by choosing a more conservative approach and removing as much tissue as possible to prevent mutilations and functional deficits.

\section{References}

[1]. Antunes AA, Filho JR, Antunes AP. DisplasiaFibrosaÓssea: Estudoretrospectivo-revisão de literatura. Rev Bras Cirur Cab Pesc. 2004, 33(1):21-26.

[2]. Cruz OL, Pessoto J, Pezato R, Alvarenga EL. Osteodistrofias do osso temporal: Revisão dos conceitosatuais, manifestaçõesclínicas e opçõesterapêuticas. Rev Bras Otorrinol. 2002, 68(1):119-26.

[3]. Júnior VS, Andrade EC, Didoni ALS, Jorge JC, Filho NS, Yoshimoto FR. Displasiafibrosa de osso temporal: relato de caso e revisão de literature. Rev Bras Otorrinol. 2004, 70(6):828-31

[4]. Altuna X, Gorostiaga F, Algaba J. Displasiafibrosamonostótica de seno frontal. A propósito de um caso.ORL-DIPS. 2004, 31(2):8487.

[5]. Botelho RA, Tornin OS, Yamashiro I, Menezes MC, Furlan S, Ridelenski M, Yamashiro R, Chagas JFS, Souza RP. Característicastomográficas da displasiafibrosa craniofacial: estudo de 14 casos. Radiol Bras. 2006, 39(4):269-272.

[6]. Moreno BA, Sànchez AL, Collado JA, Garcia AU, Cortês JM, Varela HV. Displasiafibrosamonostótica de senoesfenoidal. O.R.L. Aragon. 2007, 10(1):12-15.

[7]. Pontual ML, Tuji FM, Yoo HJ, Bóscolo FN, Almeida SM. Estudoepidemiológico da displasiafibrosa dos maxilaresnumaamostra da populaçãobrasileira. OdontolClin.-Científ. 2004, 3(1):25-30.

[8]. Lee P, Van Dop C, Migeon C. McCune-Albright syndrome: long-term follow-up. JAMA. 1986, 256:2980-2984.

[9]. Alves AL, Canavarros F, Vilela DS, Granato L, Próspero JD. Displasiafibrosa: relato de trêscasos. Rev Bras Otorrinol. 2002, 68(2):288-292.

[10]. Lustig LR, Holliday MJ, McCarthy EF, Nager GT. Fibrous Dysplasia involving the skull base and temporal bone. Arch Otolaryngol Head Neck Surg. 2001, 127:1239-1247.

[11]. Fuster MA, Martín JÁ, Rodríguez-Pereira C, Navarro JM, Molina JV. Displasiafibrosamonostótica de seno frontal com extensiónorbitária.ActaOtorrinolaringol Esp. 2002, 53:203-206.

[12]. Oliveira RB, Granato L, Korn GP, Marcon MA, Cunha AP. DisplasiaFibrosa do osso temporal: relato de doiscasos. Rev Bras Otorrinol. 2004, 70(5):695-700.

[13]. Infante VP, Goldman RS, Rapoport A. DisplasiaFibrosa do seiomaxilar: Relato de um caso. Rev Bras Cirur Cab Pesc. 2005, 34(1):47-48. 